\title{
Serological Diagnosis of Influenza A Subtype H1 on Family Poultry of Belo Horizonte, Minas Gerais and Santa Maria, Rio Grande Do Sul, in Brazil.
}

\section{-Author(s)}

Castro Filho RPL' (iD https://orcid.org/0000-0002-9300-7513 Torres ACD' (iD https://orcid.org/0000-0002-7199-6517 Marin SY' (D) https://orcid.org/0000-0002-9374-5591 Diniz SA' (iD) https://orcid.org/0000-0002-4163-3563 Matos JCCI (iD https://orcid.org/0000-0003-1489-1361 Mureb EN' (D) https://orcid.org/0000-0001-8969-0551 Resende $\mathrm{M}^{\prime}$ (DD https://orcid.org/0000-0002-6192-7489 Martins NRS' (DD https://orcid.org/0000-0001-8925-2228

Universidade Federal de Minas Gerais, UFMG, Escola de Veterinária, Departamento de Medicina Veterinária Preventiva, Av. Antônio Carlos, 6627 Caixa Postal 567. Campus Pampulha, CEP30123970, Belo Horizonte, Minas Gerais, Brasil.

\section{ABSTRACT}

Serum samples ( $n=687$ ) from Gallus gallus domesticus were collected for the investigation of antibodies to avian influenza virus (AIV-A) in the family poultry of the surrounding counties of Santa Maria/RS and the metropolitan region of Belo Horizonte/MG, totaling twenty different counties. Additional samples of seventeen $(n=17)$ free-flying ducks (C. moschata pure or hybrid with Anas platyrhynchos) were collected in Belo Horizonte. The chosen tests for the survey were performed as described by the World Organization for Animal Health (OIE), including agar gel immunodiffusion (AGID) for antibodies to AIV-A nucleoprotein (N) and haemagglutination- inhibition (HI) for antibodies to subtype $H 1$. Out of the 704 serum tests performed by AGID, eight (8/704) were revealed positive for antibodies to AIV-A N protein, with six (6/704) retested positive for subtype $\mathrm{H} 1$. Two sera tested positive by AGID were shown to be non reactive to the $\mathrm{H} 1$ subtype, suggesting specificity to another subtype. A low occurrence of antibodies to influenza A (1.13\%) was found, and mostly (75\%) specific to subtype H1. This represents an approximately 0,85\% overall occurrence for subtype H1 antibodies, with an unknown subtype specific antibodies detected in one free-flying anatid. The low occurrence of antibodies in the family poultry may suggest a low AIV-A activity during the period of study, information which remains to be confirmed by virus detection.

\section{INTRODUCTION}

Avian influenza A virus (AIV-A) is a member of Orthomyxoviridae and genus Influenzavirus. AlV-A has several structural and non-structural proteins, including the hemagglutinin $(\mathrm{H})$ and neuraminidase $(\mathrm{N})$, the envelope glycoproteins which are responsible for the characterization of the subtype of AIV-A and its pathogenicity (OIE, 2017). AIV-A is exotic to the Brazilian industrial poultry, for the conformity to the OIE standards. In addition, the poultry industry responds for an important economic and social activity, with relevance due to the export revenue, the supply of affordable meat for the national market and the generation of thousands of jobs.

Subsistence or family poultry populations may include asymptomatic hosts for a diversity of pathogens and the animal/human interactions may enable a substantial risk for transmission. Influenza virus is relevant for the public health, for other avian species and domestic an wild animals, as well as to the economy and may.

Influenza viruses have evolutionary mechanisms that allow rapid survival and dissemination throughout Nature, such as resistance in water, especially in cold regions (Stallknecht et al., 2006). Aquatic migratory birds are natural reservoirs and usually asymptomatic, with AIV-A replication occurring mostly in their digestive system with fecal- 
Castro Filho RPL, Torres ACD,

Marin SY, Diniz SA, Matos JCC,

Mureb EN, Resende M, Martins NRS
Serological Diagnosis of Influenza A Subtype $\boldsymbol{H} 1$ on Family Poultry of Belo Horizonte, Minas Gerais and Santa Maria, Rio Grande Do Sul, in Brazil. oral transmission. Several orders of birds and mammals, including human beings are susceptible hosts (Sanhong et al., 2015), and perpetuation in nature may be associated to quasispecies genetic diversity, based on the natural events of point mutation (copy error) and recombination (Jong et al., 2000).

From an epidemiological point of view, influenza outbreaks are associated with human activity which enable the proximity of domestic and wild animals, and humans, with the natural reservoirs. According to the OIE, the most affected areas occur in Asia, Europe, Northeast Africa and North America (OIE, 2017). In humans, the monitoring updates of 2016 (June 27) (WHO, 2016) revealed high activity mostly of H1N1, which was substituted by mostly subtype H3 in 2017 (WHO, 2017). Although no direct association of avian and human infections may be assumed in Brazil, close activities with live birds, such as with live bird markets must be considered of risk.

The migratory bird routes connect the entire globe and no region is completely safe (Swayne et al., 2008). The surveillance systems are today, the most effective tools for understanding AIV epidemiology dynamics and its force of dissemination, bringing the possibility of anticipating or even preventing an outbreak. This study aimed to contributing for understanding the local epidemiology of AIV activity in the family poultry in two Brazilian states.

\section{MATERIAL AND METHODS}

\section{Sample collection}

The sampling method was used in line with the available literature, setting a $5 \%$ prevalence $(p)$ and a standard deviation (s) in 2,5\%, obtaining a minimum sample size (n) of 385 animals. The applied formula according to (Lwanga \& Lemeshow, 1991) was:

$$
\mathrm{P} \pm \mathrm{t} s / \sqrt{ } \mathrm{n}
$$

Seven hundred and four (704) serum samples were examined in total. Six hundred and eighty seven (687) chickens (Gallus gallus domesticus) were collected from family poultry in the metropolitan regions of Belo Horizonte/ MG and Santa Maria/ RS, from July through November 2016, totaling twenty different counties. From these, thirty nine (39) samples were collected from the routine diagnosis of diseases at the Laboratory of Avian Diseases (UFMG), including 27 chickens and 12 ducks. Additional samples of seventeen free-flying ducks (C. moschata and hybrids with Anas platyrhynchos) were collected in Belo Horizonte (Tables 1 and 2).
Blood samples limited to no more than $0.5 \%$ of body mass (approximately $3 \mathrm{~mL}$ for adult bird and 1 $\mathrm{mL}$ for young), were preserved in individual tubes, and transported to the laboratory in isothermal cases at $0^{\circ} \mathrm{C}$, where sera were separated and stored $(-20$ ${ }^{\circ} \mathrm{C}$ ) until processing. This study was submitted and approved by the animal ethics commission of UFMG (CEUA), protocol 175/2016.

\section{(AGID) and Specific Influenza A Antigen production}

A nucleocapsid-enriched antigen was prepared from the chorioallantoic membranes (CAM) of embryonated chicken eggs that have been infected at 10 days of age and incubated for 24 hours (Beard, 1970) for the agar gel immunodiffusion (AGID). CAM were harvested, washed in PBS, homogenized, freezethawed three times, and centrifuged at $1,000 \mathrm{~g}$. The supernatant fluids were inactivated by the addition of $0.1 \%$ formalin $\left(37^{\circ} \mathrm{C}, 36 \mathrm{~h}\right)$ for use as antigen.

Table 1 - Origin of serum samples of family poultry from the metropolitan region of Belo Horizonte/MG.

\begin{tabular}{lccc}
\hline Great Belo Horizonte/MG & (n) Samples & $\begin{array}{c}\text { Gallus gallus } \\
\text { domesticus }\end{array}$ & $\begin{array}{c}\text { Cairina } \\
\text { moschata }\end{array}$ \\
\hline Laboratory of Avian Diseases & 39 & 27 & 12 \\
\hline Sabará & 20 & 20 & - \\
Ribeirão das Neves & 32 & 32 & - \\
\hline Pedro Leopoldo & 32 & 32 & - \\
Confins & 32 & 32 & - \\
Lagoa Santa & 32 & 32 & - \\
Belo Horizonte downtown & 64 & 64 & - \\
Betim & 32 & 32 & - \\
Contagem & 32 & 32 & - \\
Belo Horizonte (chickens) & 192 & 192 & - \\
Belo Horizonte (ducks) & 5 & 0 & 5 \\
Total & 512 & 495 & 17 \\
\hline
\end{tabular}

Table 2 - Origin of serum samples of family poultry from the metropolitan region of Santa Maria/RS

\begin{tabular}{lccc}
\hline Great Santa Maria/RS & (n) Samples & $\begin{array}{c}\text { Gallus gallus } \\
\text { domesticus }\end{array}$ & $\begin{array}{c}\text { Cairina } \\
\text { moschata }\end{array}$ \\
\hline Pains & 22 & 22 & - \\
São Valentim & 17 & 17 & - \\
Santo Antão & 19 & 19 & - \\
Arroio Grande & 20 & 20 & - \\
Santa Flora & 18 & 18 & - \\
Tere & 11 & 11 & - \\
Passo do Verde & 15 & 15 & - \\
Arroio do Só & 1 & 1 & - \\
Palmas & 11 & 11 & - \\
Boca do Monte & 58 & 58 & 0 \\
Total & 192 & 192 & - \\
\hline
\end{tabular}


Castro Filho RPL, Torres ACD, Marin SY, Diniz SA, Matos JCC, Mureb EN, Resende M, Martins NRS
Serological Diagnosis of Influenza A Subtype $\boldsymbol{H} 1$ on Family Poultry of Belo Horizonte, Minas Gerais and Santa Maria, Rio Grande Do Sul, in Brazil.

\section{Virus}

AIV strain A/Puerto Rico/8/ 1934 H1N1 was used for antigen preparation. Virus was diluted to $10^{-3}$ and treated with penicilin $(2,000 \mathrm{UI} / \mathrm{mL})$, streptomycin $(2$ $\mathrm{mg} / \mathrm{mL})$, gentamycin $(0.50 \mathrm{mg} / \mathrm{mL})$ and amphotericin b $(1,000 \mathrm{UI} / \mathrm{mL})$ for passage. A volume $(0.1 \mathrm{~mL})$ of the solution was inoculated into the chorio-allantoic cavity of 9 days-old specific pathogen free embryonated chicken eggs (OIE, 2015). Inoculated eggs were incubated $\left(37^{\circ} \mathrm{C} / 60 \%\right.$ humidity) (IP70D, Premium Ecológica, Belo Horizonte, Brazil) for 7 days, and chilled to $4^{\circ} \mathrm{C}$ overnight and the allantoic fluid was recovered and tested and titrated for hemagglutination ( $\mathrm{HA}$ ) activity.

\section{Positive Control Serum}

In order to obtain positive serum control to AIV antibodies, three adult SPF chickens, two females and one male, where inoculated with inactivated $(0,1 \%$ formalin) A/Puerto Rico/8/ 1934 H1N1, emulsified in complete Freund's (SIGMA, United States) (from approx. $\left.10^{5.0} \mathrm{DIE}_{50} / 0.1 \mathrm{~mL}\right)$. The inoculum $(0.5 \mathrm{~mL})$ was administrated intramuscularly (chest) of the birds, and after three consecutive 10-day interval inoculations, specific antibodies were detected in sera by AGID tests without clinical alterations.

Tests were carried out using 1\% (w/v) agarose gels with $8 \% \mathrm{NaCl}$ in $0.01 \mathrm{M}$ phosphate buffer $\mathrm{pH}$ 7.2, poured to a thickness of $3 \mathrm{~mm}$ in Petri dishes, and incubated in a humidified chamber. A 7-well rosette template cutter was used for preparing wells of approximately $5 \mathrm{~mm}$ in diameter in the agar. In the rosettes, the $\mathrm{N}$-enriched antigen was placed in the center and samples and reference sera were distributed around, placed adjacent in order to enable the demonstration of the identity line. Each well was filled to form a convex meniscus, with approximately $50 \mu \mathrm{L}$ required per well.

Wells were examined for precipitation lines each 24 hours up to 72 hours. The precipitation lines were observed against a dark background back illuminated. A specific positive result was determined when the precipitation line was continuous and linked with identity between the positive control and test sera (OIE, 2015).

\section{Hemagglutination (HA)}

Red blood cells (RBC) were separated from blood taken into an equal volume of Alsever's solution from a minimum of three SPF chickens and pooled. RBC were washed three times in PBS (0.01 M, pH 7.0-7.2) and used as $1 \%$ suspension. Twofold (base 2 ) dilutions were performed throughout. Volumes of $25 \mu \mathrm{L}$ of PBS were dispensed in each well of a plastic V-bottomed microtitre plates, and $25 \mu \mathrm{L}$ of virus suspension (inactivated allantoic fluid) placed into the first well and diluted out. For the accurate determination of the HA content, readings were made by tilting the plate. Free RBC will produce tear-shaped streaming but agglutinated RBC will not. The titration was read to the highest dilution giving complete HA without streaming (OIE, 2015). Taking into consideration the HA titers obtained, four hemagglutinating units (HAU) were calculated for use in the $\mathrm{HI}$ test.

\section{Haemagglutination inhibition (HI)}

Microwell plastic plates, PBS and RBC were similar as above. Positive and negative control antigens and antisera ran with each test, as appropriate.

Twofold (base 2) dilutions of sera were performed in $25 \mu \mathrm{L}$ of PBS up to 4,096 and added $25 \mu \mathrm{L}$ of 4 HAU of inactivated virus to each well. Reaction was allowed to occur for a minimum of 30 minutes at room temperature and $25 \mu \mathrm{L}$ of $1 \%(\mathrm{v} / \mathrm{v})$ chicken RBC were added to each, well and gently mixed. After approximately 40 minutes at room temperature, the $\mathrm{HI}$ titer was considered as the highest dilution of serum causing complete inhibition, with the free RBC producing a stream by tilting. Agglutination, as assessed by tilting the plates, did not allow stream. The validation of tests was assessed by the negative control serum (titre $<22$ or $>\log 22$ ), and the confirmation of the positive control serum titer (OIE, 2015).

\section{RESULTS}

Out of the 704 analyzed samples, eight $(n=8)$ were reactive with the AGID test, all original from the metropolitan region of Belo Horizonte/Minas Gerais. The total occurrence of reactive sera for AIV-A by AGID was of $1.13 \%$. No positive samples were found on the metropolitan region of Santa Maria/Rio Grande do Sul.

Considering the origin of the AGID reactive birds, two were from Ribeirão das Neves, two from Lagoa Santa and three chickens and one duck from Belo Horizonte (Table 3). No family poultry which arrived for routine diagnosis of disease at the Laboratory of Avian Diseases had titers to AIV-A. 
Castro Filho RPL, Torres ACD, Marin SY, Diniz SA, Matos JCC, Mureb EN, Resende M, Martins NRS
Serological Diagnosis of Influenza A Subtype $\mathrm{H} 1$ on Family Poultry of Belo Horizonte, Minas Gerais and Santa Maria, Rio Grande Do Sul, in Brazil.
Table 3 - Origin and number of samples, $\mathrm{AGID}^{*}$ and $\mathrm{HI}^{* *}$ results.

\begin{tabular}{lccc}
\hline $\begin{array}{l}\text { Metropolitan region of Belo Horizonte/MG } \\
\text { Metropolitan Region of de Belo }\end{array}$ & Samples & AGID & $\begin{array}{c}\mathrm{HI} \text { anti H1 } \\
(>16)\end{array}$ \\
$\begin{array}{l}\text { Horizonte/MG } \\
\text { Laboratory of Avian Diseases*** }\end{array}$ & 39 & 0 & 0 \\
Sabará & 20 & 0 & 0 \\
Ribeirão das Neves & 32 & 2 & 0 \\
Pedro Leopoldo & 32 & 0 & 0 \\
Confins & 32 & 0 & 0 \\
Lagoa Santa & 32 & 2 & 2 \\
Betim & 32 & 0 & 0 \\
Contagem & 32 & 0 & 0 \\
Belo Horizonte & 256 & 3 & 3 \\
Belo Horizonte (ducks) & 5 & 1 & 1 \\
\hline Total & 512 & 8 & 6 \\
\hline
\end{tabular}

*AGID agar gel immunodiffusion; ${ }^{*}$ HI hemagglutination-inhibition; ${ }^{* *}$ Family free-range poultry.

The AGID reactive sera $(n=8)$ were retested by $\mathrm{HI}$, and six (6) were found positive for antibodies to subtype $\mathrm{H} 1$ of AIV-A.

Table 4 - Hemagglutination inhibition test for antibodies to AIV-A subtype H1.

\begin{tabular}{lcc}
\hline Sera* & $H I(H 1)^{* *}$ & $\log _{2} \square$ \\
& $1 / 64$ & 6 \\
\hline MC5 & $1 / 64$ & 6 \\
MC7 & $1 / 32$ & 5 \\
MC13 & $1 / 32$ & 5 \\
LG4 & $1 / 64$ & 6 \\
LG15 & $1 / 16$ & 4 \\
P4*** & 0 & 0 \\
RB13 & 0 & 0 \\
\hline RB21 & 0 & \\
\hline
\end{tabular}

*Positive Influenza A AGID samples; ** A/ Puerto Rico/ 8/ 1934 H1N1; ***P4: duck.

The RB13 and RB21 (chicken) sera (Ribeirão das Neves), although positive on the AGID test, were negative on the $\mathrm{HI}$ test, being not specific to the $\mathrm{H} 1$ subtype. Despite all other AGID AIV-reagent sera were tested positive for AIV-A subtype $\mathrm{H} 1$, no test was attempted for other subtypes.

\section{DISCUSSION}

The epidemiological survey in family poultry of Belo Horizonte/MG and Santa Maria/RS revealed very low occurrence of antibodies to AIV-A, mostly reactive to subtype $\mathrm{H} 1$, the subtype prevalent in humans (Brazil) in 2016. Although five chickens and one duck were shown positive to subtype $H 1$, the AGID reagent sera were not tested for other subtypes, indicating the possibility of antibodies to other subtype(s), especially in the two individuals not reactive to $\mathrm{H} 1$.
Not only wild birds represent a threat for the dissemination of influenza (Brentano, 2006). Family poultry birds may also play a role for the circulation and dissemination of the Influenza A viruses, although, as shown by the results, possibly not important in the evaluated region.

The epidemiology of AIV-A was investigated in Brazil (Golono, 2009), with sampling areas at sites located in migratory bird routes in Rondônia, Pará, Maranhão, Pernambuco, São Paulo and Santa Catarina, with birds tested by RT-PCR or GeneScan. Domestic, wild and migratory birds were sampled, with $2.6 \%$ shown to be positive. LPAIV was detected in Cairina moschata (domestic duck) (0.1\%), one Sterna hirundo (Trinta-Reis-Boreal) and two chickens $(0.2 \%)$, all from the state of Pará. However, LPAIV was detected in 7/67 (10.4\%) of Spheniscus magellanicus (Magellan penguin) arriving at the coast of São Paulo state, most probably infected at arrival due to the extreme immunosuppression. The indices found in family poultry (including chickens and ducks) were lower $(0.1-0.2 \%)$ as compared to our findings, but, although slightly dissimilar to our results (1.13\%), may provide support, indicating that a low viral activity may be typical for the Brazilian environment. Considering that our findings are from birds not directly associated to migratory bird sites, although with a higher index, may be indicative that the source of AIV-A inducing antibody response in our region is different, possibly associated to virus circulating in other domestic animals and humans as well as poultry.

In another study, out of 1,093 migratory wild birds sampled on the Amazonian coastal region, also in Brazil, an occurrence of $0.82 \%$, as tested by RT-PCR, was found, with 9 positive birds (Hurtado, 2013), and index in agreement with the previous study (Golono, 2009), and slightly lower than our results. As with samples by Golono (2016), the study by Hurtado (2013) involved birds within migratory bird routes, but in contrast to our study, which evaluated resident birds. Antibodies to H1N1, also found in our study, and H3N4 were detected in wild and domestic birds on Rio de Janeiro (Oliveira et al., 2001).

A speculative association might be drawn, due to the agreement of the subtype antibodies detected in our study, and the human influenza A virus prevalent in 2016 in Brazil, in both cases the $\mathrm{H} 1$ subtype (WHO, 2016). However, it could be postulated that a low interspecies transmission may take place in Belo Horizonte and Santa Maria regions, considering the predominant type of exploitation, characterized by 
Castro Filho RPL, Torres ACD,

Marin SY, Diniz SA, Matos JCC,

Mureb EN, Resende M, Martins NRS
Serological Diagnosis of Influenza A Subtype $\mathrm{H} 1$ on Family Poultry of Belo Horizonte, Minas Gerais and Santa Maria, Rio Grande Do Sul, in Brazil. relatively small bird flocks, open areas and reduced contact. Resident birds within regions not visited by migratory reservoir birds, such as ours, may reflect a local circulation of AIV.

A serological study in Nigeria in 2016, conducted after a large scale outbreak, with hundreds of affected properties and massive economic impact, has shown a total prevalence of $4,4 \%$ by ELISA and $\mathrm{HI}$ (Oluwayelu et al., 2015) for H3N8 and H5N2 subtypes, with antibody titers to subtype $\mathrm{H} 1$ ranging from $1: 8$ to $1: 2,048$. Nigeria, as well as other parts of Africa, has been affected by the Eurasian outbreaks of highly pathogenic AIV (OIE, 2017). The epidemiology of AIV-A in Nigeria is very different from that present in Brazil. Although very low indices were found in our studies, the antibody detection alone will not reveal the entire picture and demand for virus monitoring and characterization for a better understanding.

In Grenada (Caribbean), a serological study was conducted by ELISA in 143 family poultry birds, resulting in 27 positive sera, a $18.8 \%$ occurrence (Sabarinath et al. 2011). Although the Grenada study also involved family poultry, their results were substantially different than ours, due to the geographic and epidemiological differences, the Caribbean island within the migratory north-south route receiving many migratory birds capable of carrying the Influenza A virus (Colin et al., 2014), resulting in a much higher prevalence than our region in Brazil.

A study of several species and locations of aquatic migratory ducks in Texas showed a prevalence between $0.6 \%$ and $2.0 \%$, using rRT-PCR and haemagglutination (Ferro et al., 2010). Although the prevalence was similar to this study, the epidemiological conditions are very different, considering the viral activity and diversity in the United States, including Texas, in migratory routes (CDC, 2017).

The detection of responses to AIV-A $\mathrm{H} 1$ on this study suggests a previous contact with an AIV of this subtype. The lack of clinical signs or history of disease suggests infection by a strain of low pathogenicity. However, results indicate the need for further studies on the region, especially the evaluation for virus activity with virus isolation and characterization, as knowing the virus dynamics and capability to infect mammals and birds (Brown, 2004), including the triad human, swine and birds, with a role on the formation of new viable recombinant strains (Jong et al., 2000). AIV-A in birds may be associated with infection in mammals, including humans and importantly swine Schaefer et al. (2015), and has been demonstrated in Brazil (Paiva et al., 2003).
AlV-A infection in family poultry may have a role in the generation of virus diversity, by mutation or recombination, potentially adding to public health concern and risk to the industrial poultry. LPAIV in family poultry birds may also represents a risk for wild birds in conservation (Marques et al., 2012; 2013). Antibodies to subtype $\mathrm{H} 1$ were found in one healthy free-flying duck in Belo Horizonte, in a flock with history of botulism (Silva et al., 2017), recommending for monitoring duck flocks in the region.

The AGID test is an inexpensive method for triage of flocks. Testing for antibody to the nucleoprotein enables the investigation of responses to any virus of genus influenza $A$, although especially recommended for chickens and turkeys (OIE, 2015), and requiring further analysis of sera for determining the hemagglutinin type specificity or the demonstration of virus RNA in RT-PCR.

In 2009, the World Health Organization declared the "swine flu" strain as pandemic, affecting more than 214 countries of five different continents and responsible for over 18,000 confirmed deaths (WHO, 2010). Avian influenza is increasingly important worldwide and has result in losses greater than 20 billion to the global economy, in addition to the concern for public health requiring international preparedness (OIE, 2017).

In humans, the monitoring updates of 2016 (June 27) (WHO, 2016) revealed high activity mostly of H1N1, which was substituted by mostly H3 in 2017 (WHO, 2017). Although no direct association of avian and human infections may be assumed in Brazil, close activities with live birds, such as with live bird markets must be considered of risk.

\section{ACKNOWLEDGMENTS}

We are indebted to CAPES (Federal Agency for the Support and Improvement of Higher Education) for the scholarship to RPL Castro Filho. This work would not have been possible without the structure support of Escola de Veterinária da UFMG.

\section{REFERENCES}

Beard CW. Demonstration of type-specific influenza antibody in mammalian and avian sera by immunodiffusion. Bulletin of the World Health Organization 1970;42(5):779-785.

Brentano L. Influenza aviária: panorama mundial da influenza aviária e novas propostas de diagnóstico do vírus. Anais do $5^{\circ}$ Seminário Internacional de Aves e Suínos; 2005; Florianópolis, Santa Catarina. Brasil: AveSui; 2005

Brown, H. Who confirms human-to-human avian flu transmission. Lancet 2004;363(9407):462. 
Castro Filho RPL, Torres ACD,

Marin SY, Diniz SA, Matos JCC,

Mureb EN, Resende M, Martins NRS

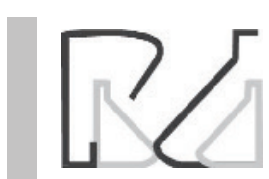

Serological Diagnosis of Influenza A Subtype $\mathrm{H} 1$ on Family Poultry of Belo Horizonte, Minas Gerais and Santa Maria, Rio Grande Do Sul, in Brazil.
CDC - Center for Disease Control and Prevention. Outbreaks of avian influenza in North America. Clifton; 2017.

Colin A, Galbraith, Jones T, Kirby J, Mundkur T. A review of migratory bird flyways and priorities for management [technical series 27]. Bonn: UNEP / CMS Secretariat; 2014. 164 p.

Ferro PJ, Budke CM, Peterson MJ, Cox D, Roltsch E, Merendino T, et al. Multiyear surveillance for avian influenza virus in waterfowl from wintering grounds, Texas Coast, USA. Emerging Infectious Diseases 2010;16(8):1224-1230.

Golono MA. Epidemiologia e caracterização molecular de vírus da Influenza em aves residentes e migratórias no Brasil [tese]. São Paulo (SP): Universidade de São Paulo; 2009.

Hurtado RF. Vigilância epidemiológica dos virus da Influenza aviária em aves migratórias na região costeira da Amazônia [tese]. São Paulo (SP): Universidade de São Paulo; 2013.

Jong JC, Rimmelzwaan GF, Fouchier RAM. et al. Influenza virus: a master of metamorphosis. Journal of Infection 2000;40(3):218-228

Lwanga, SK, Lemeshow S. Sample size determination in health studies: a practical manual. Genebra: World Health Organization; 1991.

Marques MVR, Ferreira JR, Andery DA, Fernandes A A, Araujo AV, Resende JS. Health Assessment of Captive Tinamids (Aves, Tinamiformes) in Brazil. Journal of Zoo and Wildlife Medicine 2012;43:539-548.

Marques MVR, Ferreira JR, Andery DA, Fernandes AA, Araujo AV, Resende JS, et al. Serologic, parasitic, and bacteriologic assessment of captive cracids (aves: Galliformes: Cracidae) in Brazil. Journal of Zoo and Wildlife Medicine 2013:44:27-34.

OIE - World Organisation for Animal Health. Disease information. Paris; 2015.

OIE -World Organisation for Animal Health. Avian influenza (infection with avian influenza viruses). In: OIE. Terrestrial manual. Paris; 2015.

OIE- World Organisation for Animal Health. Avian influenza portal. Paris; 2017.

Oliveira JR, Belluci MSP, Vianna JSM, Mazur C, Andrade CM, Fedullo LPL. Avaliação soroepidemiológica do vírus influenza em aves domésticas e silvestres no Estado do Rio de Janeiro. Arquivo Brasileiro de Medicina Veterinária e Zootecnia 2001;53(3):299-302.
Oluwayelu DO, Oluladun C, Aiki-Raji, Adigun OT, Olofintuyi OK, Adebiyi Al. Serological survey for avian influenza in turkeys in three states of Southwest Nigeria. Influenza Research and Treatment 2015;1-6.

Paiva TM, Ishida, Maria A, Gonçalves, Maria G, Benega. Occurrence of influenza B/Hong Kong-Like strains in Brazil, during 2002. Revista do Instituto de Medicina Tropical de São Paulo 2003;45(1):51-52.

Pinto LB, Ometto T, Araújo J, Thomazelli LM, Seixas MM, Barbosa CM, et al. Investigation of influenza $a$, west nile and newcastle disease viruses in birds from the pantanal wetlands of Mato Grosso, Brazil. Revista Brasileira de Ciência Avícola 2016;18(2):291-298.

Sabarinath A, Sabarinath GP, Tiwari KP, Kumthekar SM, Thomas D, Sharma RN. Virological and Serological Surveillance of Avian Influenza Virus in the Birds of Grenada. International Journal of Poultry Science 2011:10(8): 579-582

Sanhong L, Pang L, Ruan S, Zhang X. Global dynamics of avian influenza epidemic models with psychological effect. Computational and Mathematical Methods in Medicine 2015;1-12

Schaefer R, Rech RR, Gava D. A human-like H1N2 influenza virus detected during an outbreak of acute respiratory disease in swine. Archives of Virology 2015;160(1):29-38.

Silva ROS, Gómez SYM, Medeiros LB, Marques MVR, Silva ASG, Mureb EN et al. Antitoxin therapy of natural avian botulism outbreaks occurred in Brazil. Anaerobe 2017:48:115-117.

Stallknecht DE, Brown JD, Swayne DE, Cooper RJ, Burns RE. Persistance of $\mathrm{H} 5$ and $\mathrm{H7}$ avian influenza viruses in water. Avian Diseases 2006;51(1 Suppl):285-289

Swayne DE, Halvorson DA, et al. Diseases of poultry. Ames: Blackwell Publishing; 2008

WHO - World Health Organization. Pandemic (H1N1). Genebra; 2009.

WHO. World Health Organization. Percentage of respiratory specimens that tested positive for influenza by influenza transmisskion zone ; 2016. Available from: http://www.who.int/influenza/surveillance_monitoring/ updates/2016_06_27_influenza_update_266.jpg?ua=1

WHO. World Health Organization. Percentage of respiratory specimens that tested positive for influenza by influenza transmisskion zone; 2017. Available from: http://www.who.int/influenza/surveillance_monitoring/ updates/2017_06_26_influenza_update_292.jpg?ua=1 